\title{
COD FRACTIONS - METHODS OF MEASUREMENT AND USE IN WASTEWATER TREATMENT TECHNOLOGY
}

\author{
Sylwia MYSZOGRAJ ${ }^{1}$, Ewelina PŁUCIENNIK-KOROPCZUK, \\ Anita JAKUBASZEK, Aleksandra ŚWIETEK \\ University of Zielona Gora, Zielona Góra, Poland
}

\begin{abstract}
The paper presents the results of studies concerning the designation of COD fraction in raw wastewater. The research was conducted in four municipal mechanical-biological sewage treatment plants and one industrial sewage treatment plant. The following fractions of COD were determined: non-biodegradable (inert) soluble $\mathrm{S}_{\mathrm{I}}$, biodegradable soluble fraction $\mathrm{S}_{\mathrm{S}}$, particulate slowly degradable $\mathrm{X}_{\mathrm{S}}$ and particulate non-biodegradable $\mathrm{X}_{\mathrm{I}}$. The methodology for determining the COD fraction was based on the ATV-A131 guidelines and Łomotowski-Szpindor methodology. The real concentration of fractions in raw wastewater and the percentage of each fraction in total COD are different from data reported in the literature.
\end{abstract}

Keywords: COD fractions, raw wastewater, methodology

\section{INTRODUCTION}

Microorganisms play the most important role in biological wastewater treatment that involves the removal of biogenic compounds. It is essential that the carbon, nitrogen and phosphorus compounds occur in the forms available to them. Indicators including biochemical oxygen demand $\left(\mathrm{BOD}_{5}\right)$, chemical oxygen demand (COD) or loss on ignition (LOI) are used to determine the organic matter content. COD and LOI are measures of the total organic matter content, while $\mathrm{BOD}_{5}$ is most commonly defined as the total (soluble and particulate bound in

\footnotetext{
${ }^{1}$ Corresponding author: University of Zielona Góra, Faculty of Civil Engineering, Architecture and Environmental Engineering, Institute of Environmental Engineering, Szafrana st 15, 65-246 Zielona Góra, e-mail: s.myszograj@iis.uz.zgora.pl, +48683282574
} 
suspension) biodegradable fraction. None of these parameters provide detailed information on the quantitative ratios within the readily biodegradable fraction. This is essential when designing and defining operation assumptions for biological processes for the removal of biogenic compounds. Detailed characterization of organic matter in processes used to stabilize sewage sludge as well as issues associated with sludge liquids arising in the treatment plant are of growing importance.

One of the most significant achievements in sewage technology is COD fractionation, which makes it possible to isolate fractions depending on the size of molecules and their responsiveness to biochemical decomposition. Determination of COD fractions furnishes a detailed characteristic of sewage composition, but primarily makes it possible to determine the amount of both easily and poorly degradable organic contaminants.

\section{COD FRACTIONS}

Design of technological sewage treatment systems, in most cases, takes into account concentration of biodegradable organic matter expressed as $\mathrm{BOD}_{5}$. Determining the COD fractions additionally allows for the assessment of quantity of non-biodegradable pollutants which decrease the effectiveness of biological treatment. Therefore, in the design and modelling of biogenic component removal systems, it is preferable to use the total COD in raw sewage divided into soluble and particulate fractions. This division allows for subsequent calculations of the content of individual forms of nitrogen present in domestic wastewater. The constituent elements of total COD are presented by equation [1, 2]:

$$
\mathrm{COD}_{\text {Tot }}=\mathrm{S}_{\mathrm{S}}+\mathrm{S}_{\mathrm{I}}+\mathrm{X}_{\mathrm{S}}+\mathrm{X}_{\mathrm{I}}+\mathrm{X}_{\mathrm{H}}+\mathrm{X}_{\mathrm{A}}+\mathrm{X}_{\mathrm{P}} \quad \mathrm{gO}_{2} / \mathrm{m}^{3}
$$

where:

$\mathrm{S}_{\mathrm{s}} \quad$ - soluble readily biodegradable substrates, $\mathrm{gO}_{2} / \mathrm{m}^{3}$

$\mathrm{S}_{\mathrm{I}} \quad$ - inert soluble organic material, $\mathrm{gO}_{2} / \mathrm{m}^{3}$

$\mathrm{X}_{\mathrm{S}}$ - particulate slowly biodegradable substrates, $\mathrm{gO}_{2} / \mathrm{m}^{3}$

$\mathrm{X}_{\mathrm{I}} \quad$ - inert particulate organic material, $\mathrm{gO}_{2} / \mathrm{m}^{3}$

$\mathrm{X}_{\mathrm{H}}$ - heterotrophic organisms, $\mathrm{gO}_{2} / \mathrm{m}^{3}$

$\mathrm{X}_{\mathrm{A}}$ - autotrophic nitrifying organisms, $\mathrm{gO}_{2} / \mathrm{m}^{3}$

$\mathrm{X}_{\mathrm{P}} \quad$ - decay products, $\mathrm{gO}_{2} / \mathrm{m}^{3}$

Unless the biomass fraction is not included, this model is simplified to the form $[1,2]$ :

$$
\mathrm{COD}_{\mathrm{tot}}=\mathrm{S}_{\mathrm{S}}+\mathrm{S}_{\mathrm{I}}+\mathrm{X}_{\mathrm{S}}+\mathrm{X}_{\mathrm{I}} \quad \mathrm{gO}_{2} / \mathrm{m}^{3}
$$

The percentage ratios of the COD fractions in raw municipal sewage according to the literature data are presented in Table 1. 

TREATMENT TECHNOLOGY

Table 1. COD ratios (\%) in raw sewage according to the literature data

\begin{tabular}{|l|c|c|c|c|c|c|c|}
\hline $\begin{array}{c}\text { Research object, } \\
\text { [references] }\end{array}$ & $\mathrm{S}_{\mathrm{I}}$ & $\mathrm{S}_{\mathrm{S}}$ & $\mathrm{X}_{\mathrm{I}}$ & $\mathrm{X}_{\mathrm{S}}$ & $\mathrm{X}_{\mathrm{H}}$ & $\mathrm{X}_{\mathrm{S}}+\mathrm{X}_{\mathrm{H}}$ & VFA \\
\hline South America, [3] & 5.0 & 20.0 & 13.0 & & & 62.0 & \\
\hline Switzerland, [4] & 14.0 & 9.0 & 9.0 & 56.0 & 12.0 & 68.0 & \\
\hline Switzerland, [5] & 4.0 & 10.0 & 20.0 & 54.1 & 11.9 & 66.0 & \\
\hline Denmark, [6] & 2.0 & 20.0 & 18.0 & 40.0 & 20.0 & 60.0 & \\
\hline Denmark, [6] & 10.0 & 15.0 & 20.0 & 40.0 & 15.0 & 55.0 & 8.8 \\
\hline Spain, [6] & 8.5 & 18.3 & 24.9 & 33.3 & 15.0 & 48.3 & \\
\hline Sweden, [7] & 15.0 & 27.0 & 17.0 & 33.0 & 8.0 & 41.0 & \\
\hline Italy, [6] & 6.0 & 15.0 & 8.0 & 56.0 & 15.0 & 71.0 & \\
\hline Germany, [6] & 6.1 & 14.8 & 13.0 & 55.4 & 10.8 & 66.2 & \\
\hline North America, [8] & 12.0 & 15.0 & 14.5 & & & 59.0 & 1.4 \\
\hline North America, [6] & 5.0 & 16.0 & 13.0 & & & 66.0 & 2.4 \\
\hline France, [6] & 4.1 & 3.0 & 19.0 & & & 73.9 & \\
\hline Hungary, [6] & 4.6 & 21.9 & 23.7 & 49.9 & & & \\
\hline
\end{tabular}

The data collected in Table 1 indicated that the highest percentage ratios in the examined raw sewage are those of fractions $\mathrm{X}_{\mathrm{S}}$ or $\mathrm{X}_{\mathrm{S}}+\mathrm{X}_{\mathrm{H}}$, and the lowest - fraction $S_{\text {I. }}$ An analysis of the results given by the authors also shows that the ratio of biodegradable fractions expressed as the sum of $\mathrm{X}_{\mathrm{S}}+\mathrm{S}_{\mathrm{S}}$ is above $70 \%$, which confirms the responsiveness of sewage to biodegradation.

On the other hand, the problem of separation of COD fractions results from the lack of a definition on the basis of which it is unambiguously possible to determine the ratio of soluble and particular pollutants. For example, some authors classify colloidal fraction as particulate suspension, others as a solution. In the case of the first division, the authors report that the percentage ratio of the suspension fraction in total COD of raw household sewage is $65-79 \%$ and dissolved - 21-35\% [6]. Proponents of assignment to a fraction of colloids of compounds dissolved indicate that the percentage ratio of suspensions in household sewage is about 57\% COD and colloids and dissolved substances about $43 \%$ in total. Biodegradable organic compounds represent an average of $39 \%$ of all organic matter in wastewater, and non-biodegradable about $61 \%[9,10]$. 


\section{Biodegradable soluble fraction - $\mathrm{S}_{\mathrm{S}}$}

$\mathrm{S}_{\mathrm{S}}$ fraction is assimilated and mineralized by heterotrophic bacteria. This fraction is measured in order to determine:

- easily available sources of organic carbon in wastewater, both during design and operation,

- ratio of each COD fraction in wastewater for the purpose of mathematical modelling of the processes,

- kinetic parameters required for efficient operation of the bioreactor.

Easily biodegradable COD fraction consists of organic carbon compounds that provide energy to microorganisms. However, they have to be hydrolysed before they can diffuse and be absorbed by microorganisms $[9,10]$. The $\mathrm{S}_{\mathrm{S}}$ fraction determines the success of dephosphatation and denitrification in difficult changing conditions. It reduces the amount of oxygen returned with the active sludge, which is taken up very intensively in the early stages of the process by growing heterotrophic organisms.

The source of readily biodegradable fraction in wastewater include:

- industrial wastewater (for example, fruit and vegetable processing industry)

- products of fermentation taking place in anaerobic sewerage network conditions,

- fatty acids extruded in fermenters (in separate acid fermentation chambers), primary settling tanks, or sludge thickeners,

- products of facultative anaerobe activity in the reactor's anaerobic zone,

- leachate from municipal landfills.

\section{Suspension slowly degradable - $\mathbf{X}_{\mathbf{S}}$}

Similar to the biodegradable soluble fraction $\mathrm{S}_{\mathbf{S}}$, the $\mathrm{X}_{\mathrm{S}}$ fraction has a significant influence on the dynamics of the activated sludge process. The $\mathrm{X}_{\mathrm{S}}$ fraction consists of compounds that must be hydrolysed to simple compounds by extracellular enzymes in order to be assimilated by microorganisms $[9,10]$. The fraction bound in particulate biodegradable matter has a great influence on the dynamic behaviour of the activated sludge process, including oxygen demand, and also forms one of the main design parameters of biological nitrogen and phosphorus removal systems. During biological wastewater treatment, this fraction combines with activated sludge flocs or with membrane developing on biological beds and can therefore be removed with excessive sludge $[3,6,10]$. Roeleveld and Loosdrecht [11] recommend determining the soluble and particulate fractions by using the $0.1 \mu \mathrm{m}$ filter or precipitation of $\mathrm{Zn}(\mathrm{OH})_{2}$. The difference in the COD value obtained by filtration and precipitation is less than $1 \%$. 


\section{Non-biodegradable (inert) soluble fraction - $S_{I}$}

The $S_{\text {I }}$ fraction consists of organic compounds that do not take part in the wastewater treatment processes, do not undergo any changes. They are discharged with treated effluent. In the cases where a high proportion of the $S_{I}$ fraction occurs in wastewater, the use of biological wastewater treatment is not recommended $[5,16]$.

\section{Particulate non-biodegradable (inert) - $\mathbf{X}_{\mathbf{I}}$}

Fraction $X_{I}$ consist of undissolved pollutants [5]. It is very important when its share exceeds typical values, namely when it is greater than 0.15 of the total COD. It is then collected in the mass of the sludge and accumulates in the system. This significantly influences the course of the sewage treatment and quality of the effluent. High concentration of the $X_{I}$ fraction can disturb the maintenance of constant sludge age and nitrification. It is assumed that the size of this fraction does not change during biological treatment, its content in the influent is equal to its corresponding mass, which outflows along with excess sludge [10,11]. The amount of non-biodegradable fraction can be determined on the basis of the mass balance, i.e. the product of inflowing mass and the age of the sludge. It follows that if we are dealing with a higher sludge age, a significant part of the dry mass of activated sludge may consist of the $\mathrm{X}_{\mathrm{I}}$ fraction [11].

\section{MATERIAL AND METHODS}

The aim of the research was to determine the concentrations of COD fractions in raw wastewater flowing into a municipal wastewater treatment plant in Zielona Góra, Leszno, Sulechów and Włoszkowice as well as in industrial wastewater from industrial company in Leszno.

The results and calculations obtained have made it possible to determine percentage ratios of the individual fractions in total COD, as well as an assessment of the practical use of the COD fraction in engineering practice.

To determine the fraction of the COD in the wastewater was determined:

- Chemical oxygen demand, COD - with the potassium dichromate method, per PN-74/C-04578.03, PN-ISO 6060:2006,

- Biochemical oxygen demand, BOD - with the manometric method, using the OxiTop Control OC110 measurement system made by WTW.

\subsection{The characteristics of the research objects}

The research subjects were municipal sewage treatment plants: for the cities of Zielona Góra $\left(\mathrm{Q}_{\mathrm{d}}=51,225 \mathrm{~m}^{3} / \mathrm{d}\right)$, Sulechów $\left(\mathrm{Q}_{\mathrm{d}}=6,450 \mathrm{~m}^{3} / \mathrm{d}\right)$, Leszno $\left(\mathrm{Q}_{\mathrm{d}}=48,500\right.$ $\left.\mathrm{m}^{3} / \mathrm{d}\right)$, and Włoszakowice $\left(\mathrm{Q}_{\mathrm{d}}=1,100 \mathrm{~m}^{3} / \mathrm{d}\right)$. These are mechanical-biological 
sewage treatment plants with the function of the removal of nitrogen and phosphorus compounds, operating in low-load active sludge systems.

The factory manufactures handles, gas regulators, small household items, small parts for the automotive industry including fuel gauges, window lifts, brackets, etc. The plant uptakes water for all purposes from municipal water supply only. The water is used for the domestic needs of the staff, for the technological processes, and, in case of emergency, for firefighting. Domestic wastewater is produced in sanitary units and factory canteen $\left(25 \mathrm{~m}^{3} /\right.$ day). Industrial wastewater is generated in technological processes $\left(60 \mathrm{~m}^{3} /\right.$ day). Rainwater runoff from the plant site and roofs occurs due to precipitation and snowmelt (24,598 $\left.\mathrm{m}^{3} / \mathrm{year}\right)$. A separate sewer system operates on the premises. Test samples were taken from the local (factory) wastewater treatment plant.

\subsection{Methodology of research}

The COD fraction methodology was developed on the basis of modified ATV-A131 guidelines [16] and Łomotowski-Szpindor methodology [12].

The modified ATV-A131 methodology for the determination of fractions $\mathrm{S}_{\mathrm{S}}, \mathrm{S}_{\mathrm{I}}$, $\mathrm{X}_{\mathrm{S}}$ and $\mathrm{X}_{\mathrm{I}}$ involves characterization of $\mathrm{COD}$ and $\mathrm{BOD}_{5}$ in filtered and non-filtered samples of raw and treated sewage.

- The soluble, non-biodegradable fraction $S_{I}$ is termed as COD in filtered treated sewage $(0,45 \mu \mathrm{m})$.

- The soluble, easily biodegradable fraction $S_{S}$ is calculated from the difference of the concentration of dissolved organic contaminants SCOD determined in filtered raw sewage and the concentration of the soluble non-biodegradable fraction $\left(\mathrm{S}_{\mathrm{I}}\right)$ :

$$
\mathrm{S}_{\mathrm{S}}=\mathrm{SCOD}-\mathrm{S}_{\mathrm{I}} \quad \mathrm{gO}_{2} / \mathrm{m}^{3}
$$

- The slowly biodegradable organic fraction $X_{S}$ is defined as the difference of total $\mathrm{BOD}\left(\mathrm{BOD}_{\mathrm{T}}\right)$, calculated based on the $\mathrm{BOD}_{5}$ of non-filtered raw sewage and the biochemical decomposition coefficient $\left(\mathrm{k}_{1}=0,6\right)$ and the soluble, easily biodegradable fraction:

$$
\mathrm{X}_{\mathrm{s}}=\left(\mathrm{BOD}_{5} / \mathrm{k}_{1}\right)-\mathrm{S}_{\mathrm{s}} \quad \mathrm{gO}_{2} / \mathrm{m}^{3}
$$

- Non-biodegradable organic suspension $X_{I}$ is determined from the dependence:

$$
\mathrm{X}_{\mathrm{I}}=\mathrm{XCOD}-\mathrm{X}_{\mathrm{s}} \quad \mathrm{gO}_{2} / \mathrm{m}^{3}
$$

where:

XCOD - total organic substance concentration in suspension, 
- Total COD of raw sewage is determined as the sum of the fractions, with equation:

$$
\mathrm{COD}_{\text {Tot }}=\mathrm{S}_{\mathrm{I}}+\mathrm{S}_{\mathrm{S}}+\mathrm{X}_{\mathrm{S}}+\mathrm{X}_{\mathrm{I}} \mathrm{gO}_{2} / \mathrm{m}^{3}
$$

According to the method described by Łomotowski and Szpindor [12], COD fractions in raw sewage can be determined as summarized in Table 2.

Tabela 2. Methodology of Łomotowski and Szpindor

\begin{tabular}{|c|c|c|}
\hline Fraction of COD & Methodology & Note \\
\hline $\mathrm{S}_{\mathrm{S}}$ & $\mathrm{BOD}_{5}$ & - \\
$\mathrm{S}_{\mathrm{I}}$ & $\mathrm{COD}_{\mathrm{b}}-1,47 \mathrm{BOD}_{\mathrm{b}}$ & $\begin{array}{c}\mathrm{COD}_{\mathrm{b}} \text { i } \mathrm{BOD}_{\mathrm{b}}=\mathrm{COD} \text { and } \mathrm{BOD}_{5} \text { of } \\
\text { filtered biological treatment sewage }\end{array}$ \\
& & - \\
$\mathrm{X}_{\mathrm{S}}$ & $0,47 \mathrm{BOD}_{5}$ & - \\
$\mathrm{X}_{\mathrm{I}}$ & $\mathrm{COD}-1,47 \mathrm{BOD}_{5}-\mathrm{S}_{\mathrm{I}}$ & \\
\hline
\end{tabular}

\section{RESULTS AND DISCUSSION}

The mean values of organic contaminant indicators calculated for raw sewage and sewage treated in the municipal sewage treatment plants: Zielona Góra, Sulechów, Leszno and Włoszakowice and industry wastewater treatment plant are presented in Table 3. Sewage fed into the treatment plants differed with respect to the contaminant concentration ranges.

Table 3. COD and $\mathrm{BOD}_{5}$ in raw and treated sewage

\begin{tabular}{|c|c|c|c|c|c|c|}
\hline \multicolumn{7}{|c|}{ Raw sewage, $\mathrm{gO}_{2} / \mathrm{m}^{3}$} \\
\hline & \multirow{2}{*}{ WWTP } & \multicolumn{2}{|c|}{ COD } & \multicolumn{2}{|c|}{$\mathrm{BOD}_{5}$} & \multirow{2}{*}{$\begin{array}{c}\mathrm{COD} / \mathrm{BOD}_{5} \\
\text { non-filtred } \\
\text { sewage }\end{array}$} \\
\hline & & non-filtred & filtred & non-filtred & filtred & \\
\hline 1 & Zielona Góra & 740 & 220 & 320 & 154 & 2.3 \\
\hline 2 & Leszno & 320 & 200 & 160 & 14 & 2.0 \\
\hline 3 & Sulechów & 1320 & 280 & 510 & 179 & 2.6 \\
\hline 4 & Włoszakowice & 1000 & 760 & 680 & 78 & 1.5 \\
\hline 5 & Industry & 400 & 360 & 280 & 20 & 1.4 \\
\hline \multicolumn{7}{|c|}{ Treated sewage, $\mathrm{gO}_{2} / \mathrm{m}^{3}$} \\
\hline \multirow{2}{*}{\multicolumn{2}{|c|}{ WWTP }} & \multicolumn{2}{|c|}{ COD } & \multicolumn{2}{|c|}{$\mathrm{BOD}_{5}$} & \multirow{2}{*}{$\begin{array}{c}\mathrm{COD} \mathrm{BOD}_{5} \\
\text { non-filtred } \\
\text { sewage }\end{array}$} \\
\hline & & non-filtred & filtred & non-filtred & filtred & \\
\hline 1 & Zielona Góra & 40 & 21 & 5 & 3 & 8.0 \\
\hline 2 & Leszno & 50 & 27 & 7 & 6 & 7.1 \\
\hline 3 & Sulechów & 80 & 60 & 13 & 11 & 6.2 \\
\hline 4 & Włoszakowice & 76 & 19 & 16 & 12 & 4.8 \\
\hline 5 & Industry & 50 & 14 & 7 & 6 & 7.1 \\
\hline
\end{tabular}


The highest COD content in the raw sewage was found in wastewater inflowing to the Sulechow treatment plant $\left(1,320 \mathrm{gO}_{2} / \mathrm{m}^{3}\right)$, while the lowest one in the Leszno inflow $\left(320 \mathrm{gO}_{2} / \mathrm{m}^{3}\right)$. The high $\mathrm{COD}$ of sewage in Sulechów and Włoszakowice was most likely due to the significant share of sewage $\mathrm{BOD}_{5}$ values for the tested raw sewage samples ranged from $160 \mathrm{gO}_{2} / \mathrm{m}^{3}$ (Leszno) to $680 \mathrm{gO}_{2} / \mathrm{m}^{3}$ (Włoszakowice). For all tested wastewater samples the COD/BOD ratio for unfiltered raw sewage ranged from 1.4 to 2.6, which demonstrates a high content of biodegradable organic matter fraction, even in the case of industrial wastewater. In treated unfiltered effluent, COD values ranged from $40 \mathrm{gO}_{2} / \mathrm{m}^{3}$ (Zielona Góra) to $80 \mathrm{gO}_{2} / \mathrm{m}^{3}$ (Sulechów), while $\mathrm{BOD}_{5}$ was less than 15 $\mathrm{gO}_{2} / \mathrm{m}^{3}$ at the outflow of three treatment plants (Zielona Góra, Leszno, Sulechów). In the treated effluent at Włoszakowice plant, $\mathrm{BOD}_{5}$ it was close to the required value at $16 \mathrm{gO}_{2} / \mathrm{m}^{3}$. $\mathrm{COD} / \mathrm{BOD}_{5}$ ratio for treated unfiltered wastewater ranged from 4.8 to 8.0 .

The efficiency of removal of organic compounds from wastewater, expressed as COD for the tested sewage treatment plants ranged from $84.4 \%$ (Leszno) to 94.6\% (Zielona Góra).

COD values determined according to ATV-A131 and Łomotowski and Szpindor methodology were summarized in Table 4.

Table 4. COD fractions values

\begin{tabular}{|c|c|c|c|c|c|c|c|}
\hline \multicolumn{7}{|c|}{ Procedure ATV-A131 $\mathrm{gO}_{2} / \mathrm{m}^{3}$} & \multirow{2}{*}{$\begin{array}{c}\text { Sum of fractions } \\
\text { COD } \\
\% \\
\%\end{array}$} \\
\hline \multicolumn{2}{|r|}{ Sample } & $X_{S}$ & $\mathrm{X}_{\mathrm{I}}$ & $\mathrm{S}_{\mathrm{S}}$ & $\mathrm{S}_{\mathrm{I}}$ & $\mathrm{COD}_{\mathrm{Tot}}$ & \\
\hline 1 & Zielona Góra & 334 & 111 & 199 & 21 & 666 & 11 \\
\hline 2 & Leszno & 94 & 31 & 173 & 27 & 325 & -2 \\
\hline 3 & Sulechów & 630 & 210 & 220 & 60 & 1120 & 18 \\
\hline 4 & Włoszakowice & 392 & 131 & 741 & 19 & 1283 & -22 \\
\hline 5 & Industry & 121 & 40 & 346 & 14 & 521 & -23 \\
\hline \multicolumn{7}{|c|}{ Methodology of Łomotowski and Szpindor $\mathrm{gO}_{2} / \mathrm{m}^{3}$} & $\begin{array}{c}\text { Sum of fractions } \\
\text { COD }\end{array}$ \\
\hline \multicolumn{2}{|r|}{ Sample } & $X_{S}$ & $X_{I}$ & $\mathrm{~S}_{\mathrm{S}}$ & $\mathrm{S}_{\mathrm{I}}$ & $\mathrm{COD}_{\mathrm{Tot}}$ & $\%$ \\
\hline 1 & Zielona Góra & 150 & 253 & 320 & 17 & 740 & 0 \\
\hline 2 & Leszno & 75 & 67 & 160 & 18 & 320 & 0 \\
\hline 3 & Sulechów & 240 & 526 & 510 & 44 & 1320 & 0 \\
\hline 4 & Włoszakowice & 320 & 0 & 680 & 1 & 1001 & $-0,1$ \\
\hline 5 & Industry & 132 & 0 & 280 & 5 & 417 & $-4,2$ \\
\hline
\end{tabular}

The fraction values calculated according to the method given by Łomotowski and Szpindor result, for the tested samples, in a lower error when comparing the calculated COD and COD determined by the test. 
The content of specific COD fractions in total COD for test samples calculated according to ATV-A131 and according to Lomotowski and Szpindor methodology is presented in Fig. 1 and Fig. 2.

The calculations made using the ATV-A131 procedure, as well as according to Łomotowski and Szpindor demonstrate that soluble biodegradable substances i.e. fraction $\mathrm{S}_{\mathrm{S}}$ constitute the largest fraction in the tested wastewater. The smallest was the $\mathrm{S}_{\mathrm{I}}$ fraction - soluble non-biodegradable.

The values calculated according to ATV-A131 for the biodegradable COD fraction $\left(\mathrm{X}_{\mathrm{S}}+\mathrm{S}_{\mathrm{S}}\right)$ ranged from $267 \mathrm{gO}_{2} / \mathrm{m}^{3}$ to $1,133 \mathrm{gO}_{2} / \mathrm{m}^{3}$, while the inert fractions $\left(\mathrm{X}_{\mathrm{I}}+\mathrm{S}_{\mathrm{I}}\right)$ ranged from $54 \mathrm{gO}_{2} / \mathrm{m}^{3}$ to $270 \mathrm{gO}_{2} / \mathrm{m}^{3}$.

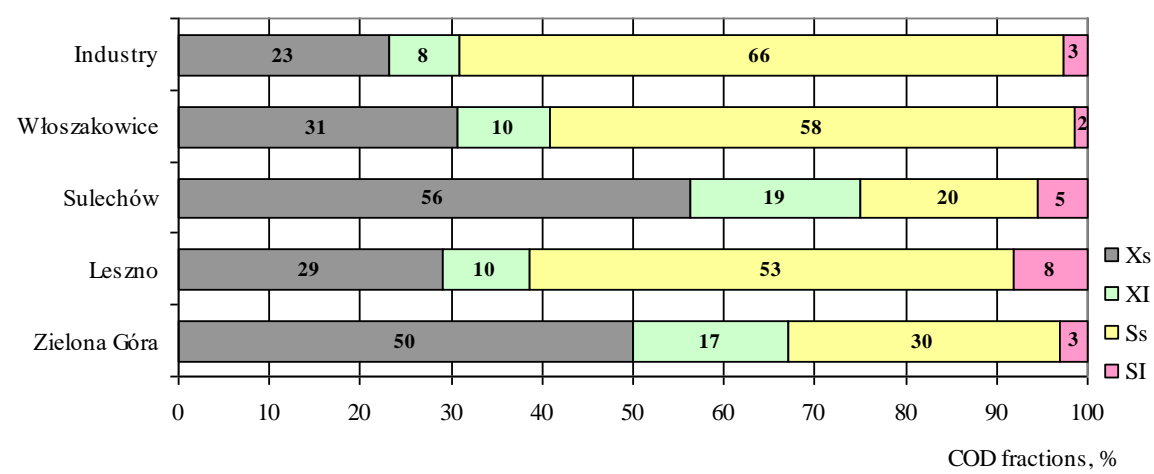

Fig. 1. COD fractions in total COD for test samples calculated according to ATV-A131

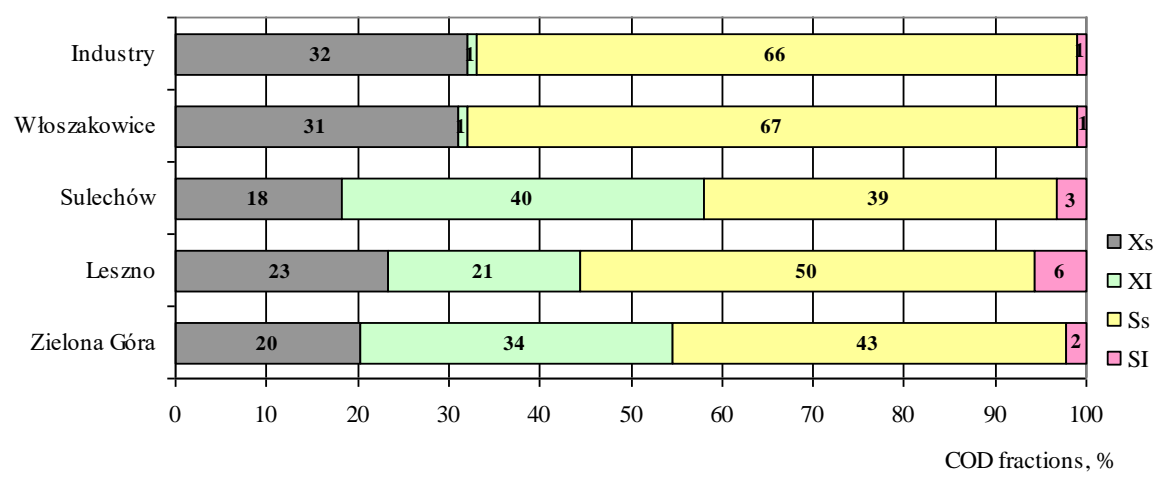

Fig. 2. COD fractions in total COD for test samples calculated according to Łomotowski and Szpindor methodology

The content of the inert COD fraction $\left(\mathrm{X}_{\mathrm{I}}+\mathrm{S}_{\mathrm{I}}\right)$ ranged between $10 \%$ and $24 \%$, hence the biodegradable fraction in the wastewater was between $80 \%$ to $90 \%$. 
Significant differences in values for the tested wastewater samples were observed when dividing COD into soluble fraction and particulate biodegradable fraction. In the wastewater from Zielona Góra and Sulechowa the $\mathrm{X}_{\mathrm{S}}$ comprised about $50 \%$, while in samples from Leszno and Włoszakowice - about 30\%. A similar patterns was observed for the $X_{I}$ fraction. Soluble biodegradable fraction $\left(S_{S}\right)$ content in wastewater from Zielona Góra and Sulechowa was respectively $30 \%$ and $20 \%$, while in wastewater from Leszno and Włoszakowice - more than $50 \%$. In all wastewater samples, the non-biodegradable soluble fraction did not exceed $10 \%$.

Comparisons of COD fractions in wastewater reported in literature with the values determined by the tests (according to the ATV method and the methodology given by Łomotowski and Szpindor is presented in Table 5.

Table 5. Comparisons of COD fractions in wastewater reported in literature with the values determined by the tests

\begin{tabular}{|c|c|c|c|c|c|c|c|}
\hline \multirow{2}{*}{ Fraction } & $\begin{array}{c}\text { Kappeler } \\
\text { and Gujer } \\
{[4]}\end{array}$ & $\begin{array}{c}\text { Sözen } \\
{[14]}\end{array}$ & $\begin{array}{c}\text { Kalinowska } \\
\text { Oleszkiewicz } \\
{[15]}\end{array}$ & $\begin{array}{c}\text { Ekama } \\
{[3]}\end{array}$ & $\begin{array}{c}\text { Henze } \\
{[13]}\end{array}$ & $\begin{array}{c}\text { ATV- } \\
\text { A131 } \\
{[16]}\end{array}$ & $\begin{array}{c}\text { methodology } \\
\text { of } \\
\text { Łomotowski } \\
\text { and Szpindor }\end{array}$ \\
\hline $\mathrm{S}_{\mathrm{S}}$ & $10-20$ & 9 & $12-25$ & $20-25$ & $24-32$ & $19.6-66.4$ & $38.6-67.9$ \\
\hline $\mathrm{S}_{\mathrm{I}}$ & $7-11$ & 4 & $8-10$ & $8-10$ & $8-11$ & $1.5-8.3$ & $0.1-5.6$ \\
\hline $\mathrm{X}_{\mathrm{S}}$ & $53-60$ & 77 & 50 & $35-60$ & $43-49$ & $23.2-56.2$ & $18.2-32.0$ \\
\hline $\mathrm{X}_{\mathrm{I}}$ & $7-15$ & 10 & 15 & $5-7$ & $11-20$ & $7.7-18.8$ & $0-39.9$ \\
\hline
\end{tabular}

\section{CONCLUSIONS}

There is currently no uniform methodology for determining the content of COD fractions. The results obtained using different methods can vary considerably. Averaged data from literature is most commonly used are, but this leads to large errors.

Analysis of the test results and the performed calculations allows the following conclusions:

1. In all tested wastewater samples, the readily biodegradable fractions $\mathrm{S}_{\mathrm{S}}$ or $\mathrm{X}_{\mathrm{S}}$ had the largest share in the total COD.

2. For non-biodegradable fractions $S_{I}$ and $X_{I}$, values consistent with those given in the literature were obtained.

3. Significant differences in comparison of the tested samples with the literature data were observed for the total COD divided into soluble and particulate slurry bound readily biodegradable fractions. 


\section{REFERENCES}

1. Płuciennik-Koropczuk E., Sadecka Z., Myszograj S.: COD fractions in raw and mechanically treated wastewater. Civil and Environmental Engineering Reports, No. 11, (2013), 101-113.

2. Sadecka Z., Jędrczak A., Płuciennik-Koropczuk E., Myszograj S., Suchowska-Kisielewicz M.: COD fractions in sewage flowing into Polish sewage treatment plants. Chemical and Biochemical Engineering Quarterly, Vol. 27, no. 2, (2013), 185-195.

3. Ekama G.A., Dold P.,L., Marais G.v.R.: Procedures for determining influent COD fractions and the maximum specific growth rate of heterotrophs in activated sludge systems. Water Science and Technology, 18 (1986) 94.

4. Kappeler, J., Gujer, W.: Estimation of kinetic parameters of heterotrophic biomass under aerobic conditions and characterization of wastewater for activated sludge modelling. Water Science and Technology, 25 (1992) 125.

5. Rieger, L., Koch, G., Kühni, M., Gujer, W., Siegrist, H.: The eawag Bio-p Module for activated sludge model No. 3. Water Research, 35 (2001) 3887.

6. Pasztor, I., Thury, P., Pulai, J.: Chemical oxygen demand fractions of municipal wastewater for modeling of wastewater treatment. International Journal of Environmental Science and Technology, 6 (2009) 51.

7. Xu, S., Hultman, B.: Experiences in wastewater characterization and model calibration for the activated sludge process. Water Science Technology, 33 (1996) 89.

8. Melcer, H., Dold ,P.L., Jones R.M., Bye Ch.M., Takacs I.,Stensel, H.D., Wilson, A.W., Sun, P., Bury, S.: Treatment Processes and Systems. Methods for Wastewater Characterization in Activated Sludge Modeling. Water Environment Research Foundation, Alexandria, (2003) 596.

9. Henze M.: Oczyszczanie ścieków. Procesy biologiczne i chemiczne. Kielce 2000.

10. Kappeler J., Gujer W.: Estimation of kinetic parameters of heterotrophic biomas under aerobic conditions and characterization of wastewater for activated sludge modelling. Water Science and Technology, 25 (6) (1992), 125-139.

11. Orhon D., Okutman D.: Respirometrics assessment of residual organic matter for domestic sewage. Enzyme and Microbial Technology, 32(5) (2003), 560566.

12. Łomotowski J., Szpindor A.: Nowoczesne systemy oczyszczania, Arkady 2002. 


\section{FRAKCJE CHZT - METODY POMIARU ORAZ ZASTOSOWANIE W TECHNOLOGII OCZYSZCZANIA ŚCIEKÓW}

\section{Streszczenie}

W artykule przedstawiono wyniki badań, których celem było wyznaczanie frakcji ChZT w ściekach surowych. Badania przeprowadzono w czterech komunalnych mechanicznobiologicznych oczyszczalniach ścieków i oczyszczalni ścieków przemysłowych. Określono następujące frakcje ChZT: inertna rozpuszczona $\mathrm{S}_{\mathrm{I}}$, biodegradowalna rozpuszczona $\mathrm{S}_{\mathrm{S}}$, związana w zawiesinie biologicznie łatworozkładalnej $\mathrm{X}_{\mathrm{S}}$ i związana w zawiesinie nieulegająca biodegradacji $X_{I}$. Metodologia określania frakcji ChZT została oparta na wytycznych ATV-A131 i metodologii Łomotowskiego-Szpindora. Uzyskany udział frakcji w całkowitym ChZT w ściekach surowych różnił się od danych literaturowych.

Słowa kluczowe: frakcje ChZT, ścieki surowe, metodologia

Editor received the manuscript: 20.09 .2016 